\title{
МЕДИЧНЕ ЗАБЕЗПЕЧЕННЯ ВОДОЛАЗНИХ СПУСКІВ І РОБІТ У СИСТЕМІ ДЕРЖАВНОÏ СЛУЖБИ УКРАЇНИ З НАДЗВИЧАЙНИХ СИТУАЦІЙ
}

\author{
${ }^{1}$ Тернопільський національний медичний університет \\ імені І. Я. Горбачевського МОЗ України, м. Тернопіль, Україна \\ ${ }^{2}$ Аварійно-рятувальний загін спеціального призначення управління Державної служби України \\ з надзвичайних ситуацій у Тернопільській області, м. Тернопіль, Україна
}

\begin{abstract}
Мета: дослідити організацію медичного забезпечення водолазних спусків і робіт у системі Державної служби України з надзвичайних ситуацій (ДСНС), її основних завдань, сил та засобів, які залучають до медичного забезпечення, обсягів медичної допомоги на всіх етапах, інші питання координації взаємодії.

Матеріали і методи. Використано чинні нормативно-правові акти та керівні документи щодо організації медичного забезпечення водолазних спусків і робіт у системі ДСНС України. Методи дослідження: бібліосемантичний, аналітичний, системного підходу.

Результати. У статті досліджено медичне забезпечення водолазної служби та підпорядкованих їй формувань, органів і підрозділів служби цивільного захисту. Розглянуто порядок отримання медичного допуску для водолазів до виконання водолазних спусків та робіт. Визначено фрункціональні обов'язки та повноваження як штатного медичного персоналу, так й інших медичних працівників, яких залучають до здійснення заходів із медичного забезпечення. Проаналізовано обсяг надання медичної допомоги під час залучення водолазів до виконання водолазних спусків та робіт, а також у період між ними.

Висновки. Медичне забезпечення водолазної служби в системі дСНС України є обов'язковою та невід'ємною частиною її функціонування. Заходи з медичного забезпечення водолазної служби поширюються на осіб рядового і начальницького складу служби цивільного захисту та працівників професійних аварійно-рятувальних служб, що входять до складу таких фрормувань та спрямовані на збереження та зміцнення здоров'я водолазів, підвищення їх працездатності, профрілактику розвитку негативних медичних наслідків перебування в умовах підвищеного тиску, раннього виявлення та лікування професійних захворювань.
\end{abstract}

КЛЮчОВІ СЛОВА: медичне забезпечення; водолазна служба; водолазні спуски та роботи; служба цивільного захисту; Державна служба України з надзвичайних ситуацій.

До сил цивільного захисту належать спеціалізовані аварійно-рятувальні служби, які мають підготовлених рятувальників і відповідні засоби цивільного захисту та призначені для проведення аварійно-рятувальних й інших невідкладних робіт з особливим ризиком для життя та здоров'я, зокрема для проведення водолазних спусків і робіт [1].

3 метою ефективного керівництва заходами щодо організації, забезпечення та проведення водолазних спусків і робіт, а також контролю за ними, оптимального використання за призначенням водолазних підрозділів та окремих посадових осіб органів та підрозділів Державної служби України з надзвичайних ситуацій (ДСНС) створена та фрункціонує водолазна служба ДСНС.

Водолазна служба ДСНС у своїй діяльності керується Конституцією України, указами Президента України та постановами Верховної Ради України, прийнятими відповідно до Конституції та законів України, актами Кабінету Міністрів України, іншими актами законодавства України.

(с) В. Л. Смірнова, В. В. Репута, 2021
Водолазна служба дСНС складається із водолазної служби апарату ДСНС, водолазних служб територіальних органів ДСНС та підпорядкованих їм формувань, підприємств сорери управління ДСНС, фрормувань центрального підпорядкування оперативно-рятувальної служби цивільного захисту, а також водолазних підрозділів, окремих посадових осіб, що входять до складу таких фрормувань.

Водолазна служба ДСНС взаємодіє з водолазними службами інших органів державної влади, підприємств, установ та організацій під час проведення аварійно-рятувальних та інших невідкладних робіт на водних об'єктах, під час реалізації єдиної науково-технічної політики щодо створення водолазної техніки та застосування водолазних технологій, навчання фахівців, віднесених до водолазної спеціалізації, організації та проведення зборів фрахівців водолазного складу та лікарів (фельдшерів), які відповідають за медичне забезпечення водолазних спусків і робіт [2].

Мета роботи: дослідити організацію медичного забезпечення водолазних спусків і робіт у сис- 
темі Державної служби України з надзвичайних ситуацій, її основних завдань, сил та засобів, які залучають до медичного забезпечення, обсягів медичної допомоги на всіх етапах, інші питання координації взаємодії.

Матеріали і методи. Використано чинні нормативно-правові акти та керівні документи щодо організації медичного забезпечення водолазних спусків і робіт у системі ДСНС України. Методи дослідження: бібліосемантичний, аналітичний, системного підходу.

Результати дослідження та їх обговорення. Медичне забезпечення водолазної служби та підпорядкованих їй фрормувань, органів і підрозділів служби цивільного захисту є обов'язковою та невід'ємною частиною її функціонування.

Враховуючи ризики для життя та здоров'я водолазів під час виконання своїх професійних обов'язків, медичне забезпечення передбачає встановлення підвищеного та безперервного контролю, спрямованого на збереження їх здоров'я і працездатності, як у процесі водолазних спусків, так і між ними.

Виконання водолазних спусків і робіт передбачає обов'язкове отримання попереднього допуску, одним із елементів якого є відсутність медичних протипоказань за виконання ряду вимог.

По-перше, кожен водолаз повинен отримати особисту медичну книжку водолаза, фрорма якої встановлена відповідно до чинного законодавства [3] та видається за місцем навчання особи, що отримала первинну водолазну кваліфікацію «водолаз 3 класу».

По-друге, допуск надається після щорічної перевірки стану здоров'я водолазною медичною комісією (ВМК) або військово-лікарською комісією (ВЛК), що дає висновок зі зазначенням граничної глибини занурювання.

По-третє, безпосередньо перед залученням до усіх видів водолазних спусків і робіт проводиться комплексний медичний огляд водолаза штатним медичним працівником водолазного підрозділу.

Водолаз отримує допуск до залучення лише за умов виконання усіх вищеперерахованих вимог.

Водолазні спуски та роботи виконуються силами та засобами водолазних підрозділів, що укомплектовані водолазною технікою і медичним персоналом, допущеним до забезпечення водолазних спусків та робіт відповідно до вимог чинного законодавства.

Безпосереднє зобов'язання 3 організації медичного забезпечення водолазних спусків покладається на керівника водолазних робіт, який призначається з урахуванням характеру майбутніх водолазних робіт. Зазвичай керівником водолазних робіт є начальник групи (відділення) водолазно-рятувальних робіт [3].
Водолазні спуски поділяють:

1) за глибиною:

- водолазні спуски на малі глибини - до 12 м;

- водолазні спуски на середні глибини - від 12 до $60 \mathrm{м}$;

- глибоководні водолазні спуски - на глибину понад $60 \mathrm{M;}$

2) за призначенням:

- спуск водолазний робочий;

- спуск водолазний навчальний;

- спуск водолазний тренувальний (у тому чис-

лі у барокамері);

- спуск водолазний кваліфікаційний;

- спуск водолазний експериментальний.

На період залучення (відрядження) для виконання водолазних робіт за наказом керівника органу та підрозділу призначаються, у тому числі особи, які здійснюють медичне забезпечення з числа штатних медичних працівників відповідно до кваліфікаційних вимог і фрункціональних обов'язків [4].

За відсутності штатного лікаря (фельдшера) водолазного підрозділу наказом керівника органу та підрозділу медичне забезпечення водолазних спусків і робіт покладають на іншого медичного працівника органу та підрозділу, який має спеціальну підготовку та отримав допуск до медичного забезпечення водолазних спусків і робіт, наданий водолазною кваліфрікаційною комісією (ВКК).

Медичне забезпечення експериментальних і навчальних водолазних спусків покладають тільки на штатних лікарів (фельдшерів). Водночас лікарі забезпечують всі види водолазних спусків і робіт на будь-які глибини, а фельдшери мають право забезпечувати водолазні спуски та роботи на глибини до 60 м (крім експериментальних і навчальних водолазних спусків). Штатна посада лікаря (фельдшера) спеціальної підготовки передбачає щомісяця обов'язкову участь в тренувальних спусках у водолазних барокамерах. Перебування водолазів та медичного персоналу під підвищеним тиском у барокамерах $є$ різновидом водолазного спуску.

Штатні лікарі (фельдшери) в обов'язковому порядку проходять ВМК (ВЛК) щороку та повинні бути визнані придатними за станом здоров'я до перебування у водолазних барокамерах під тиском до 1 мПа (10 кгс/см² або 100 мм вод. ст.), а також успішно скласти іспит ВКК на допуск до медичного забезпечення водолазних спусків і робіт, в якому зазначають глибини занурення, типи водолазного спорядження, види спусків і робіт.

Інші (позаштатні) медичні працівники органів та підрозділів служби цивільного захисту, яких залучають до медичного забезпечення водолазних спусків і робіт, - зобов'язані проходити ВМК (ВЛК) щороку безпосередньо перед складанням 
іспиту ВКК на допуск до медичного забезпечення водолазних спусків і робіт.

Варто розділяти поняття власне «медичне забезпечення водолазів» (у період між водолазними спусками та роботами) та «медичне забезпечення водолазних спусків» (під час водолазних спусків і робіт на малі та середні глибини) [3].

Медичне забезпечення водолазів у період між водолазними спусками та роботами включає:

1) щорічний медичний огляд із записом результатів до особистої медичної книжки водолаза;

2) щомісячні медичні огляди водолазів;

3) надання медичної допомоги із записом діагнозу і проведеного лікування до особистої медичної книжки водолаза та амбулаторного журналу;

4) контроль за режимами праці та відпочинку;

5) контроль за харчуванням водолазів;

6) контроль за фрізичною підготовкою.

Контроль за режимами праці та відпочинку водолазів здійснюють за участю лікаря (фельдшера). Загальний час перебування водолаза під тиском протягом доби (24 год) не має перевищувати 6 годин. Черговий спуск з урахуванням кількості робочих спусків водолаза в тому самому діапазоні глибин протягом робочої зміни дозволяється не раніше ніж через 12 год після закінчення останнього спуску в робочій зміні. В окремих випадках за загального часу перебування водолаза під тиском протягом доби від 6 до 10 год черговий спуск дозволяється не раніше ніж через 24 год після закінчення поточного спуску. Якщо загальний час перебування водолаза під тиском протягом доби перевищив 10 год, черговий спуск дозволяється не раніше ніж через 48 год після закінчення поточного спуску. Перед спуском під воду водолазу потрібно надати відпочинок, тривалість якого регламентується інструкціями [3].

Лікар (фельдшер) бере участь у складанні планів водолазних спусків і щоквартальних перевірок фрактичної участі водолазів у водолазних спусках.

Повним відпочинком водолазів до і після спусків вважається звільнення їх від усіх видів робіт. У цей період допускається тільки медичний огляд. Після добового чергування і нічної вахти водолази протягом 12 год до спусків не допускаються.

Кількість робочих спусків водолаза в тому самому діапазоні глибин протягом робочої зміни не має перевищувати:

1) 8 спусків - на глибини до 6 м;

2) 6 спусків - на глибини від 7 до 12 м;

3) 4 спуски - на глибини від 13 до 20 м;

4) 2 спуски - на глибини від 21 до 40 м;

5) 1 спуск - на глибини від 41 до 60 м.

У разі повторних спусків на різні глибини загальна кількість спусків протягом робочої зміни не має перевищувати кількості спусків, дозволених для найбільшої глибини.
Після експериментальних водолазних спусків, пов'язаних із випробуваннями нового спорядження, техніки, режимів декомпресії, обов'язковий час перебування водолазів в органі чи підрозділі незалежно від глибини спуску має складати одну добу. Тривалість відпочинку водолазів може збільшуватись у разі спусків малотренованих водолазів, а також після виконання важких підводних робіт. Під час цілодобових водолазних робіт водолази кожної зміни повинні спати не менше 8 год на добу. Зменшувати тривалість відпочинку водолазів до 4-6 год дозволяється у випадках, пов'язаних із проведенням водолазних аварійнорятувальних та інших невідкладних робіт і наданням допомоги аварійному водолазу.

Харчування водолазів організовують так, щоб кожен водолаз мав можливість отримувати гарячу їжу за 2 год до початку спуску, а також відразу після підйому на поверхню. У разі тривалої декомпресії в барокамері (понад 5-6 год) і лікувальної рекомпресії гарячу їжу передають в камеру. Їжа має бути висококалорійною і не надмірною за кількістю. До раціону харчування в день спусків не входять продукти, що викликають інтенсивне газоутворення в кишечнику.

Медичне забезпечення водолазних спусків і робіт на малі та середні глибини охоплює:

1) медичний огляд та опитування водолазів щодо наявності скарг на стан здоров'я перед спуском;

2) контроль за приготуванням дихальних газових сумішей;

3) проведення аналізів повітря, дихальних газових сумішей, регенеративних і поглинальних речовин;

4) санітарно-гігієнічний контроль за підготовкою і використанням водолазного спорядження, жорстких водолазних пристроїв і барокамер;

5) контроль за самопочуттям водолазів під час роботи під водою;

6) вибір режимів декомпресії та контроль за їх проведенням;

7) надання медичної допомоги водолазам та їх лікування в разі захворювань і травм;

8) контроль за встановленим режимом праці та відпочинку водолазів;

9) облік і звітність щодо професійних захворювань водолазів.

Результати медичного огляду та опитування водолазів заносять у журнал медичного забезпечення водолазів, фрорму якого визначено чинним законодавством [3].

Протипоказаннями до водолазних спусків $€$ :

- будь-які скарги на стан здоров'я водолаза;

- особиста відмова водолаза від спуску (з будьяких причин);

- незадовільний морально-психологічний стан, нервово-психічне збудження; 
- ознаки алкогольного сп'яніння, впливу наркотичних, психотропних речовин та їх наслідки.

Протипоказання у даному контексті варто розглядати як абсолютні, тобто такі, що унеможливлюють виконання водолазом своїх функціональних обов'язків у зв'язку з потенційним ризиком для здоров'я та життя, водночас відносних протипоказань не існує.

За наявності скарг на стан здоров'я водолазів направляють на огляд лікаря (фельдшера) для вирішення питання про допуск до подальших спусків, обстеження та лікування.

До санітарно-гігієнічного контролю за підготовкою і використанням водолазного спорядження і барокамер входить спостереження за своєчасністю і якістю їх дезінфекції.

Контроль за самопочуттям водолазів під час роботи під водою здійснюють шляхом періодичних (не рідше ніж через 5 хв) запитів про самопочуття по сигнальному кінцю або засобами підводного зв'язку. У разі поганого самопочуття водолаза або за відсутності відповіді на черговий запит про самопочуття негайно вживають всіх необхідних заходів із надання допомоги водолазу.

Надання домедичної та екстреної медичної допомоги у разі гострих професійних захворювань водолазів, підводних травм здійснюють згідно 3 діючими стандартами надання медичної допомоги [3]. Домедичну допомогу можуть надавати в порядку взаємодопомоги особи без медичної освіти 3 числа особового складу водолазного підрозділу (водолазний спеціаліст, водолази 1, 2 класів; I, II груп спеціалізації робіт), які пройшли відповідну підготовку та отримали допуск ВКК.

Режим декомпресії обирають окремо для кожного спуску водолаза (водолазів). Під час процесу декомпресії точність утримання глибини (тиску) має бути не менше ніж $\pm 0,5$ м.

Якщо водолаз під час підйому згідно з режимом декомпресії пропустить першу зупинку, його необхідно щонайшвидше (протягом 3 хв) спустити на глибину на 4 м нижче першої зупинки, зазначеної в обраному режимі. На цій зупинці водолаза витримують 5 хв, а потім проводять декомпресію згідно з продовженим режимом (час підйому, зворотного занурення і перебування на ґрунті на 4 м нижче першої зупинки зараховується як час перебування на ґрунті: 10 м - 4 хв; 8 м - 5 хв тощо).

Якщо під час підйому за режимом декомпресії водолаз піднявся на поверхню, його необхідно знову спустити на ґрунт, протримати там 5 хв, а потім піднімати згідно з продовженим режимом декомпресії відповідно до загального часу перебування водолаза на ґрунті плюс час підйому, підняття на поверхню, зворотного занурення і повторного перебування на ґрунті.

Під час лікування гострих профресійних водолазних захворювань використовують водолазну аптечку, комплектацію та порядок використання якої визначається інструкцією [3].

Після перенесених гострих професійних водолазних захворювань, що завершилися повним одужанням, лікар (фельдшер) на основі результатів спостережень і консультацій звільняє водолаза від спусків під воду (рахуючи 3 дня завершення лікувальної рекомпресії або інших лікувальних заходів, що проводилися під час захворювання) на такі строки:

- отруєння киснем, вуглекислим і вихлопними газами - 7 діб;

- декомпресійна хвороба легкої форми - 10 діб;

- декомпресійна хвороба середньої фрорми 15 діб;

- декомпресійна хвороба тяжкої фрорми - 20 діб.

Після баротравми легень і декомпресійної хвороби зі синдромом Меньєра період звільнення від спусків під воду або придатність до водолазних спусків визначає ВМК (ВЛК). Після інших перенесених захворювань строки звільнення водолаза від спусків під воду встановлює штатний медичний працівник на основі висновку закладу охорони здоров'я, в якому водолаз проходив лікування.

\section{Висновки}

Медичне забезпечення водолазної служби в системі ДСНС України є обов'язковою та невід'ємною частиною її фрункціонування. Заходи з медичного забезпечення водолазної служби поширюються на осіб рядового і начальницького складу служби цивільного захисту та працівників професійних аварійно-рятувальних служб, що входять до складу таких фрормувань та спрямовані на збереження та зміцнення здоров'я водолазів, підвищення їх працездатності, профрілактику розвитку негативних медичних наслідків перебування в умовах підвищеного тиску, раннього виявлення та лікування професійних захворювань.

Перспективи подальших досліджень. Розробка пропозицій щодо удосконалення чинного законодавства, яке регламентує медичне забезпечення водолазних спусків та робіт у системі дСНС України на засадах доказової медицини.

\section{Список літератури}

1. Кодекс цивільного захисту України від 02.10.2012 р. № 5403-VI [Електронний ресурс] // Відомості Верховної Ради України. - 2013. - № 34-35. - Ст. 458. - Режим доступу : https://zakon.rada.gov.ua/laws/show/5403-17\#Text.

2. Про затвердження Довідника квалісрікаційних характеристик професій працівників у сорері цивільного захисту : наказ ДСНС України від 05.12.2018 р. № 707 [Електронний ресурс]. - Режим доступу : https://zakon.rada.gov.ua/rada/ show/v0707388-18\#Text. 
3. Про затвердження Інструкції з організації водолазних спусків та робіт у Державній службі України з надзвичайних ситуацій : наказ МВС України від 01.03.2019 р. № 150 [Електронний ресурс] // Офріційний вісник України. - 2019. № 30. - Ст. 1081, код акта 94108/2019. - Режим доступу : https://zakon.rada.gov.ua/laws/show/z0300-19\#Text.

4. Про затвердження Положення про Водолазну службу Державної служби України з надзвичайних ситуацій : наказ МВС України від 15.07.2016 р. № 674 [Електронний ресурс] // Офіційний вісник України. - 2016. - № 66. - Ст. 2231, код акта 82855/2016. - Режим доступу : https://zakon.rada.gov.ua/laws/show/z1102-16\#Text.

\title{
References
}

1. (2013). Kodeks tsyvilnoho zakhystu Ukrayiny vid 02.10.2012 No 5403-VI [Code of Civil Protection of Ukraine dated 02.10.2012 № 5403-VI]. Vidomosti Verkhovnoyi Rady Ukrayiny - Bulletin of the Verkhovna Rada of Ukraine, 34-35, 1802, (458). - Retrieved from: https://zakon.rada.gov.ua/laws/show/5403-17\#Text [in Ukrainian].

2. (2018). Nakaz DSNS Ukrayiny vid 05.12.2018 No 707 «Pro zatverdzhennya Dovidnyka kvalifikatsiynykh kharakterystyk profesiy pratsivnykiv u sferi tsyvilnoho zakhystu» [Order of the SES of Ukraine dated 05.12.2018 707 "On approval of the Handbook of qualification characteristics of professions of workers in the field of civil protection"]. - zakon.rada.gov.ua. Retrieved from: https://zakon.rada.gov.ua/rada/show/v0707388-18\#Text [in Ukrainian].

3. (2019). Nakaz MVS Ukrayiny vid 01.03.2019 No 150 «Pro zatverdzhennya Instruktsiyi z orhanizatsiyi vodolaznykh spuskiv ta robit u Derzhavniy sluzhbi Ukrayiny z nadzvychaynykh sytuatsiy» [Order of the Ministry of Internal Affairs of Ukraine dated 01.03.2019 No 150 "On approval of the Instruction on the organization of diving descents and works in the State Service of Ukraine for Emergencies"]. Ofitsiynyy visnyk Ukrayiny - Official Gazette of Ukraine, 30, 260. Retrieved from: https://zakon.rada.gov.ua/laws/show/z0300-19\#Text [in Ukrainian].

4. (2016). Nakaz MVS Ukrayiny vid 15.07.2016 No 674 «Pro zatverdzhennya Polozhennya pro Vodolaznu sluzhbu Derzhavnoyi sluzhby Ukrayiny z nadzvychaynykh sytuatsiy» [Order of the Ministry of Internal Affairs of Ukraine dated 15.07.2016 No 674 "On approval of the Regulations on the Diving Service of the State Service of Ukraine for Emergencies"]. Ofitsiynyy visnyk Ukrayiny - Official Gazette of Ukraine, 66, 425. Retrieved from: https://zakon.rada.gov.ua/laws/show/ z1102-16\#Text [in Ukrainian].

\section{MEDICAL SUPPORT OF DIVING DESCENTS AND WORKS IN THE SYSTEM OF THE STATE EMERGENCY SERVICE OF UKRAINE}

V. L. Smirnova ${ }^{1}$, V. V. Reputa ${ }^{2}$

${ }^{1}$ I. Horbachevsky Ternopil National Medical University, Ternopil, Ukraine

${ }^{2}$ Emergency Rescue Detachment of Special Purpose of the Department of the SES of Ukraine in Ternopil region,

Ternopil, Ukraine

Purpose: to investigate the organization of medical support of the diving descents and works in the system of the State Emergency Service of Ukraine (SES), its main tasks, forces and means involved in medical support, extent of medical care at all stages, other issues of coordination.

Materials and Methods. Current regulations and guiding documents on the organization of medical support measures of diving descents and works in the system of the SES of Ukraine were used. Research methods: biblio-semantic, analytical, systems approach.

Results. The article reviewing the medical support of the diving service and its subordinate formations, bodies and units of the civil defense service The procedure for obtaining a medical permit for divers to perform diving descents and works is considered. The functional responsibilities and authorities of both full-time medical staff and other healthcare professionals involved in medical support are defined. The extent of medical care during the involvement of divers for diving descents and works, as well as in the period between them is analyzed.

Conclusions. Medical support of the diving service is a component of medical support in the system of the SES of Ukraine. Medical support of the diving service apply to members of the rank and file or a senior officers of the Civil Defense Service and employees of professional rescue services, which are part of such formations and are aimed at preserving and strengthening the health of divers, improving their performance, prevention of adverse medical consequences being in conditions under pressure, early detection and treatment of occupational diseases.

KEY WORDS: medical support; diving service; diving descents and works; civil protection service; State Emergency Service of Ukraine.

Рукопис надійшов до редакції 11.01.2021 р.

\author{
Відомості про авторів: \\ Смірнова Валентина Леонідівна - кандидат медичних наук, доцент кафедри громадського здоров'я та \\ управління охороною здоров'я Тернопільського національного медичного університету імені \\ І. Я. Горбачевського МОЗ України; тел.: +38(0352) 52-72-33. \\ Репута Віктор Володимирович - магістр медицини, старший лейтенант служби цивільного захисту, \\ начальник (лікар) Пункту охорони здоров'я Аварійно-рятувального загону спеціального призначення \\ управління Державної служби України з надзвичайних ситуацій у Тернопільській області; \\ тел.: +38(0352) 26-80-06.
}

